\title{
ANALISIS KUALITAS LAYANAN TOKO ONLINE TERHADAP KEPUASAN MASYARAKAT
}

\author{
Made Adhiguna Samvara ${ }^{1}$, Hidayanti ${ }^{2}$ \\ Fakultas Ekonomi, Universitas Prima Indonesia \\ madhiguna@yahoo.com ${ }^{1}, \underline{\text { hidayanti@unprimdn.ac.id }}{ }^{2}$
}

\begin{abstract}
Online stores are generally known as e-commerce or electronic commerce is an industry type where the sale and purchase of products / services is done through the internet media. As we all know, the development of online business in Indonesia continues to experience rapid increase and progress by using internet media. This study aims to determine the types of online store services that are most often complained of by people in Medan in the use of buying and selling transactions, how does the influence of the quality of online shop services on the satisfaction of public transactions in the city of Medan, service quality factors that have a dominant influence on the satisfaction of people in the Medan City transaction and what improvement efforts should be made by the online store company in improving the quality of service to achieve satisfaction of public transactions in the city of Medan. The hypothesis of this study is the quality of service significantly influences the satisfaction of the people of Medan. The results showed that the service most frequently complained by the people was that the goods purchased did not match what was received. The results also showed that the quality of services provided by the company affected the level of satisfaction of public transactions in the city of Medan with a coefficient of determination of $66.2 \%$ variable reliability was the most dominant determinant of service quality that could increase the satisfaction of public transactions in the city of Medan.
\end{abstract}

Keywords: Service Quality, Online Stores, Community Satisfaction

\section{PENDAHULUAN}

Toko online secara umum dikenal sebagai e-commerce atau electronic commerce adalah tipe industri di mana penjualan dan pembelian produk/jasa dilakukan melalui media internet. Sebagaimana kita ketahui bersama perkembangan bisnis online di Indonesia terus mengalami peningkatan dan kemajuan yang sangat pesat dengan menggunakan mediainternet. Di awal tahun 2017 ini, Menkominfo merilis data bahwa nilai transaksi online di Indonesia selama tahun 2016 mencapai angka US\$ 4,89 miliar, atau sekitar Rp. 68 triliun. Angka tersebut tentu merupakan angka perkiraan, sebab adalah pekerjaan yang sulit menghitung setiap transaksi online di Indonesia. Namun angka US\$ 4,89 miliar yang diperoleh selama 2016 tersebut jauh lebih tinggi dibandingkan dengan nominal transaksi pada tahun 2015 yang sebesar US\$3,56 miliar. Jumlah konsumen belanja online di Indonesia juga meningkat pada 2016 lalu, dan menduduki jumlah tertinggi selama lima tahun terakhir. Per Desember 2016, terdapat 8,7 juta konsumen yang bertransaksi di toko online, jumlah ini meningkat pesat dibandingkan dengan jumlah konsumen tahun 2015 yang hanya sebesar 7,4 juta konsumen. (https://onlineterpercaya.com, 2017). Seiring berkembangnya teknologi internet di Indonesia, 
memunculkan banyak sekali startup e-commerce. Mereka membangun toko online yang menjual produk sangat lengkap seperti mall dengan kelebihannya masing-masing, tujuannya adalah untuk mewadahi para penjual dan pembeli untuk melakukan transaksi secara mudah dan cepat tanpa repot hanya cukup di depan laptop, tab atau smartphone selama perangkat tersebutterhubungdenganinternet.Salahsatutrenyangpalingjelasterlihatdariindustri digital di Indonesia adalah banyaknya situs e-commerce yang muncul. Daftar toko online populer di Indonesia, yang dibedakan berdasarkan model bisnisnya, yaitu forum online dan iklan baris, situs Business to Consumer (B2C), serta marketplace Consumer to Consumer (C2C). (Pratama, 2016)

Tujuan pelayanan prima dapat memberikan rasa puas dan kepercayaan pada konsumennya. Dalam pelaksanaannya pelayanan prima merupakan pelayanan yang sangat baik dan melampaui harapan pelanggan dan pelayanan yang memiliki ciri khas kualitas (quality nice). Kualitas memberikan suatu dorongan kepada pelanggan untuk menjalin hubungan yang kuat dengan perusahaan. Pada jangka panjang ikatan seperti ini memungkinkan perusahaan untuk memahami harapan serta kebutuhan pelanggan.

Sebuah riset yang dilakukan oleh Google dan lembaga informasi konsumen GfK Indonesia menunjukkan, sepanjang 2017 konsumen dari Surabaya adalah yang paling sering

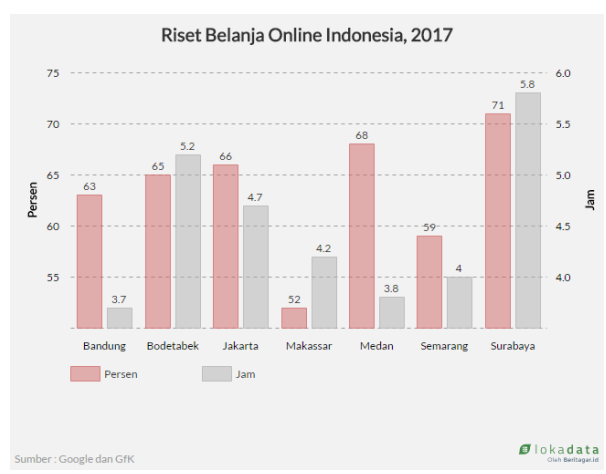

melakukan belanja daring dengan presentasi mencapai 71 persen, disusul Medan (68 persen), dan Jakarta (66 persen).

Konsumen di Surabaya bisa menghabiskan waktu untuk belanja daring selama 5,8 jam. Sementara, untuk konsumen di Bogor, Depok, Tangerang, dan Bekasi menghabiskan waktu 5,2 jam, konsumen di Jakarta menghabiskan waktu 4,7 jam dan konsumen di Medan menghabiskan waktu 3,8 jam. (Nirmala, 2018)

Menjamurnya perdagangan lewat dunia maya ini bukan tak menimbulkan masalah. Tahun 2015, aduan tentang belanja online masuk dalam sepuluh besar pengaduan di Yayasan Lembaga Konsumen Indonesia (YLKI) dan berada di urutan keempat. Tahun berikutnya, aduan tentang belanja online ini masuk ke posisi ketiga. Hal yang paling banyak diadukan adalah kendala refund, ketidaksesuaian informasi produk, dan lamanyapengiriman. 
Sampai saat ini, belum ada beleid yang secara khusus dan terperinci mengatur tentang perdagangan elektronik. Undang-Undang Nomor 7 Tahun 2014 tentang Perdagangan memang menyinggung soal Perdagangan Melalui Sistem Elektronik (PMSE). Undang-Undang No. 11 tahun 2008 tentang Informasi dan Elektronika (UU ITE) yang belum lama ini direvisi juga sering menjadi landasan transaksi elektronik. Namun, keduanya masih bersifat umum tak secara khusus mengatur soal perdagangan online. (Zuhra, 2017)

Menurut Staf Bidang Pengaduan dan Hukum YLKI Abdul Baasith, tingkat pengaduan konsumen terhadap belanja online meningkat signifikan pada Desember 2017. Jumlah keluhan meningkat sebanyak 46\%, di antaranya bersumber dari Hari Belanja Online Nasional (Harbolnas) pada 12 Desember 2017.

Tabel 1.Keluhan Pengguna Jasa Toko Online

\begin{tabular}{|l|l|l|}
\hline No & Keluhan & Persentase \\
\hline 1 & Lambatnya respon komplain & $44 \%$ \\
\hline 2 & Belum diterimanya barang & $36 \%$ \\
\hline 3 & Sistem merugikan & $20 \%$ \\
\hline 4 & Tidak diberikannya refund & $17 \%$ \\
\hline 5 & Dugaan Penipuan & $11 \%$ \\
\hline 6 & Barang yang dibeli tidak sesuai & $9 \%$ \\
\hline 7 & Dugaan kejahatan siber & $8 \%$ \\
\hline 8 & Cacat Produk & $6 \%$ \\
\hline 9 & Pelayanan & $2 \%$ \\
\hline 10 & Harga & $1 \%$ \\
\hline 11 & Informasi & $1 \%$ \\
\hline 12 & Terlambatnya penerimaan barang & $1 \%$ \\
\hline
\end{tabular}

Sumber:https://katadata.co.id/berita/2018

Tuntutan konsumen sudah dipayungi dengan hadirnya Undang- undang Konsumen yang melindungi mereka dari rendahnya kualitas jasa yang diberikan perusahaan. Undang-undang (UU) No. 8 tahun 1999 tentang Perlindungan Konsumen (UU Konsumen) yang efektif sejak tanggal 20 April 2000 menjadi payung hukum bagi tuntutan konsumen. Undang-undang ini menampung segala sesuatu yang berhubungan dengan keluhan konsumen terhadap produsen. Berdasarkan UU tersebut, produsen bertanggung jawab memberikan ganti rugi atas kerugian konsumen akibat mengonsumsi barang/jasa yang dihasilkan, namun masyarakat masih banyak yang belum menyadari bahwa konsumen jasa juga termasuk di dalam ketentuan UU Konsumen.

Berdasarkan fenomena yang terjadi di atas termasuk yang merupakan permasalahan yang juga dihadapi oleh masyarakat di daerah Kota Medan tentang kualitas layanan toko online dalam memberikan kepuasan masyarakat maka peneliti tertarik untuk melakukan penelitian ini. 
Penelitian ini akan membahas jenis layanan toko online yang paling sering dikeluhkan oleh masyarakat di Kota Medan dalam penggunaan jasa transaksi jual beli, pengaruh kualitas layanan toko online terhadap kepuasan bertransaksi masyarakat di Kota Medan, faktor kualitas layanan yang memiliki pengaruh dominan terhadap kepuasan bertransaksi masyarakat Kota Medan dan upaya perbaikan apakah yang seharusnya dilakukan oleh perusahaan toko online dalam meningkatkan kualitas layanan untuk mencapai kepuasan bertransaksi masyarakat di KotaMedan?

\section{KAJIAN LITERATUR}

(Rahmayanty, 2013) Layanan prima adalah pelayanan dengan standar kualitas yang tinggi dan selalu mengikuti perkembangan kebutuhan pelanggan setiap saat, secara konsisten dan akurat (handal), berorientasi pada kepuasan pelanggan, selalu mengikuti perkembangan standar internasional/ISO, dan menerapkan manajemen mutu total/konsistensi dan kesadaran mutu yang tinggi (high quality consciousness) seperti customer orientation (fokus pelanggan), robotics, QC-Circless (siklus kendali mutu), automation (otomatisasi), discipline in the workplace (disiplin), quality improvement (perbaikan mutu), zero defects (kerusakan nol), dan sebagainya. (Muhammad, 2014) Keunggulan pelayanan yaitu jenis pelayanan yang integrated untuk seluruh keperluan jasa pendidikan, seperti kemudahan, ketepatan, keakuratan dan pelayanan pendukung lain. pegawai perusahaan, yaitu seluruh karyawan dari tingkat bawah sampai tingkat atas sesuai dengan tugas dantanggung jawabnya memliki kecakapan, dan pengetahuan di dalam pelaksanaan pelayanan. (Isra, jose, 2017) Dalam penelitiannya yang berjudul pengaruh kualitas pelayanan terhadap kepuasan konsumen Uber Car, membuktikan bahwa kualitas pelayanan berpengaruh signifikan terhadap kepuasan konsumen Uber Car dengan variabel dominan pada responsivness (daya tanggap). Panjaitan dan Yuliati 2016, dalam penelitiannya menyimpulkan bahwa kualitas pelayanan berpengaruh signifikan terhadap kepuasan pelanggan pada JNE cabang Bandung.

(Wijayanto, 2015)Dalam penelitiannya yang berjudul pengaruh kualitas pelayanan terhadap kepuasan nasabah Bank, membuktikan bahwa kualitas pelayanan berpengaruh signifikan terhadap kepuasan nasabah Bank Jateng Syariah Cabang Surakarta dengan variabel dominan bukti fisik dan ketanggapan. (Arianto, 2018) Dalam penelitiannya menyimpulkan bahwa kualitas pelayanan berpengaruh positif dan signifikan terhadap kepuasan dan loyalitas pengunjung dalam menggunakan jasa hotel Rizen Kedaton Bogor. (Rahmayanty, 2013) Dalam mengevaluasi jasa yang bersifat intangible (tak berwujud fisik), pelanggan umumnya menggunakan beberapa atribut berikut:

1. Bukti langsung (tangibles), meliputi fasilitas fisik, perlengkapan, pegawai, dan saranakomunikasi

2. Keandalan (reliability), kemampuan memberikan pelayanan yang dijanjikan dengan 
segera, akurat danmemuaskan

3. Daya tanggap (responsiveness), keinginan para staff dan karyawan untuk membantu pelanggan dan memberikan pelayanan dengan cepattanggap

4. Jaminan (assurance), mencakup pengetahuan, kemampuan, kesopanan, dan sifat dapat dipercaya yang dimiliki para staff; bebas dari bahaya, risiko atau keraguraguan.

5. Empati (empathy), meliputi kemudahan dalam melakukan hubungan, komunikasi yang baik, perhatian pribadi dan memahami kebutuhan pelanggan.

(Lupiyoadi, 2006) Kepuasan merupakan tingkat perasaan dimana seseorang menyatakan hasil perbandingan atas kinerja produk (jasa) yang diterima dan diharapkan. (Yamit, 2013) Kepuasan pelanggan adalah hasil (outcome) yang dirasakan atas penggunaan produk dan jasa, sama atau melebihi harapan yang diinginkan. (Muhammad, 2014)Satisfaction sebagai pemenuhan yang menyenangkan (pleasurable fulfillment) yaitu konsumen merasakan bahwa konsumsi tersebut dapat memenuhi kebutuhan, keinginan, tujuan dan lain sebagainya yang disebut dengan pleasurable fulfillment. Kepuasan konsumen (consumer satisfaction) didefinisikan sebagai keseluruhan sikap yang ditunjukkan konsumen atas barang atau jasa setelah mereka memperoleh danmenggunakannya.(Mowen, 2002)

(Yamit, 2013) Kepuasan pelanggan dapat ditingkatkan dengan cara meningkatkan kualitas pelayanan kepada pelanggan dengan beberapa usaha sebagai berikut:

a. Reliabilitas: fungsi pelayanan sesuai dengan yangditetapkan

b. Security:keamanan

c. Credibility: meningkatkan sikap mental petugas untuk bekerja giat danjujur

d. Responsiveness: kecepatan dan ketepatanpelayanan

e. Communication: meningkatkan efektifitas komunikasi denganklien

f. Understanding the costumer: sistem dan prosedur pelayanan yang menghargai kemampuan mitra, meningkatkan keberpihakan kepada masyarakat.

Hipotesis penelitian ini adalah kualitas layanan berpengaruh secara signifikan terhadap kepuasan masyarakat kota Medan.

\section{METODE}

Penelitian ini menggunakan pendekatan kuantitatif. (Rakhmat, 2004) Analisis kuantitatif menggambarkan berbagai analisis statistik, bermacam alat ukur, procesing data dan analisis isi. Jenis penelitian ini merupakan penelitian deskriptif kuantitatif. Penelitian deskriptif diartikan melukiskan variabel demi variabel, satu demi satu dengan tujuan untuk mengumpulkan informasi aktual secara rinci dan mengidentifikasi masalah. Dengan sifat penelitian adalah explanatif. (Kriyantono, 2007)Survei eksplanatif menjelaskan hubungan antara 
dua atau lebih variabel, membuat hipotesis sebagai asumsi awal untuk menjelaskan hubungan antarvariabel yang diteliti.

Variabel penelitian ini terdiri dari variabel bebas yaitu kualitas layanan terbagi menjadi lima dimensi yaitu (X1) tangibles, (X2) reliability, (X3) responsiveness, (X4) assurance, (X5) empathy dan variabel terikat adalah kepuasan masyarakat $(\mathrm{Y})$, variabel- variabel penelitian ini akan diturunkan menjadi indikator untuk dapat merancang instrumen penelitian yaitu pertanyaan-pertanyaan dalam kuesioner.

Tabel 2. Indikator-indikator variabel Penelitian

\begin{tabular}{|c|c|c|c|}
\hline Variabel & Indikator & $\begin{array}{c}\text { Jml. } \\
\text { Pertanyaan }\end{array}$ & $\begin{array}{c}\text { Skala } \\
\text { Pengukuran }\end{array}$ \\
\hline \multicolumn{4}{|l|}{ Kualitas Layanan } \\
\hline Tangible(X1) & $\begin{array}{l}\text { 1. Perlengkapan dan sarana } \\
\text { prasarana } \\
\text { 2. Fasilitas }\end{array}$ & $\begin{array}{l}2 \\
2\end{array}$ & $\begin{array}{l}\text { Likert } \\
\text { Likert }\end{array}$ \\
\hline Reliability (X2) & $\begin{array}{l}\text { 1. Pelayanan yang akurat } \\
\text { 2. Pelayanan yang sesuai } \\
\text { dengandijanjikan }\end{array}$ & $\begin{array}{l}2 \\
2\end{array}$ & $\begin{array}{l}\text { Likert } \\
\text { Likert }\end{array}$ \\
\hline Responsiveness (X3) & $\begin{array}{l}\text { 1. Karyawan membantu } \\
\text { pelanggan } \\
\text { 2. Pelayanan secara cepat } \\
\text { dantepat }\end{array}$ & $\begin{array}{l}2 \\
2\end{array}$ & $\begin{array}{l}\text { Likert } \\
\text { Likert }\end{array}$ \\
\hline Assurance (X4) & $\begin{array}{l}\text { 1. Pengetahuan } \\
\text { 2. Kepercayaan }\end{array}$ & $\begin{array}{l}2 \\
2 \\
\end{array}$ & $\begin{array}{l}\text { Likert } \\
\text { Likert }\end{array}$ \\
\hline Empathy(X5) & $\begin{array}{l}\text { 1. Kemudahan } \\
\text { berkomunikasi } \\
\text { 2. Perhatian danmemahami } \\
\text { pelanggan }\end{array}$ & $\begin{array}{l}2 \\
2\end{array}$ & $\begin{array}{l}\text { Likert } \\
\text { Likert }\end{array}$ \\
\hline \multirow[t]{2}{*}{$\begin{array}{l}\text { Kepuasan } \\
\text { Masyarakat (Y) }\end{array}$} & $\begin{array}{l}\text { 1. Fungsi pelayanan sesuai } \\
\text { dengan yang ditetapkan } \\
\text { (Reliabilitas) } \\
\text { 2. Keamanan(Security) }\end{array}$ & $\begin{array}{l}2 \\
2\end{array}$ & $\begin{array}{l}\text { Likert } \\
\text { Likert }\end{array}$ \\
\hline & $\begin{array}{l}\text { 3. } \begin{array}{l}\text { Kecepatan dan ketepatan } \\
\text { pelayanan }\end{array} \\
\text { (Responsiveness) } \\
\text { 4. Efektivitas komunikasi } \\
\text { dengan klien } \\
\text { (Communication) } \\
\text { 5. Keberpihakan kepada } \\
\text { masyarakat } \\
\text { (Understanding } \\
\text { costumers) }\end{array}$ & 2 & $\begin{array}{l}\text { Likert } \\
\text { Likert } \\
\text { Likert }\end{array}$ \\
\hline
\end{tabular}

Sumber: data penelitian diolah 2019 
Populasi dalam penelitian ini adalah masyarakat di Kota Medan yang menggunakan jasa Toko Online dengan kriteria usia 20-44 tahun. Penetapan usia ini berdasarkan asumsi peneliti bahwa usia tersebut masyarakat lebih cenderung menggunakan jasa Toko Online untuk memenuhi kebutuhan hidup dan membutuhkan pelayanan terbaik. Berdasarkan data dari Badan Pusat Statistik Kota Medan untuk jumlah penduduk Kota Medan Tahun 2015 yang berusia dari 20-29 tahun berjumlah941.159 jiwa (sumber pemkomedan.go.id). Dengan demikian populasi dalam penelitian ini adalah berjumlah 941.159 orang, seperti tabel dibawah ini:

Tabel 3. Populasi Penelitian

\begin{tabular}{|l|l|l|l|l|}
\hline No & Umur & Laki-laki & Perempuan & Jumlah \\
\hline 1 & $20-24$ & 121784 & 128830 & 250614 \\
\hline 2 & $25-29$ & 98470 & 100090 & 198560 \\
\hline 3 & $30-34$ & 86995 & 90398 & 177393 \\
\hline 4 & $35-39$ & 80632 & 84551 & 165183 \\
\hline 5 & $40-44$ & 73456 & 75953 & 149409 \\
\hline Total & & 461337 & 479822 & 941159 \\
\hline
\end{tabular}

Sumber: BPS Kota Medan2015

Teknik sampling yang digunakan dalam penelitian ini adalah nonprobability sampling, jenis sampling yang digunakan adalah accidental sampling yaitu pengambilan sampel dengan cara kebetulan asalkan responden sesuai untuk dijadikan sampel penelitian yaitu pengguna jasa online di Kota Medan. Jumlah sampel yang diambil adalah 352 responden. (Rakhmat, 2004)Penentuan jumlah sampel ini berdasarkan penggunaan rumus Yamane :

$$
n=\frac{N}{\mathrm{Nd}^{2}+1}=\frac{941.159}{\left(941.159 \times 0.05^{2}\right)+1}=351,57=352
$$

Dimana:

$$
\begin{aligned}
& \mathrm{n}: \text { jumlah sampel } \\
& \mathrm{N} \text { : jumlah populasi } \\
& \mathrm{d}: \text { presisi (tingkat kesalahan } 5 \% \text { ) }
\end{aligned}
$$

Teknik pengumpulan data dilakukan dengan wawancara dan menyebarkan kuesioner kepada responden sejumlah 352 orang untuk mendapatkan persepsi yang jelas tentang kualitas layanan Toko Online dalam memenuhi kepuasan bertransaksi jual beli masyarakat Kota 
Medan.Kuesioner yang telah dirancang sebelum dibagikan kepada responden penelitian maka akan dilakukan pengujian validitas dan reabilitas dengan membagikan kuesioner kepada 30 orang responden diluar dari sampel penelitian. Kuesioner yang telah valid dan reliabel dapat langsung dibagikan kepada 352 responden. Kuesioner yang telah diisi oleh responden maka datanya akan diinput untuk dilakukan pengujian asumsi klasik.

\section{HASIL DAN DISKUSI}

Untuk mendapatkan gambaran nyata pada saat ini tentang permasalahan jenis layanan toko online yang sering dikeluhkan, maka peneliti melakukan wawancara awal dengan beberapa masyarakat Kota Medan. Setelah wawancara awal maka peneliti memperoleh informasi beberapa jenis layanan toko online yang sering dikeluhkan dan peneliti mengambil 8 (delapan) jenis layanan toko online yang sering terjadi di masyarakat kota Medan.

Adapun 8 (delapan) jenis layanan toko online yang sering terjadi di masyarakat kota Medan yaitu:

1. Lambatnya responkomplain

2. Pengiriman barang tidak tepatwaktu

3. Tidak adarefund

4. Dugaanpenipuan

5. Barang yang dibeli tidak sesuai dengan yang diterima

6. Barang yang diterima dalam kondisicacat

7. Kurangnya ketersediaan barang yang dijual

8. Gangguan sistem danjaringan

Peneliti selanjutnya menyebarkan kuesioner untuk mengetahui dari 8 (delapan) jenis keluhan tersebut yang mana merupakan keluhan yang terbanyak dirasakan oleh konsumen toko online dan mendapatkan informasi tambahan lain tentang keluhan yang dirasakan selain 8 (delapan) jenis keluhan yang sudah dirumuskan. Dari ke delapan keluhan yang disediakan, konsumen toko online diberikan kesempatan untuk memilih salah satu jenis keluhan yang dirasakan. Berdasarkan 352 kuesioner yang disebarkan kepada konsumen toko online, maka diperoleh hasil sebagai berikut: 
Tabel 4. 8 (delapan) peringkat keluhan pengguna Toko Online

\begin{tabular}{|l|l|l|l|}
\hline No & Keluhan & Jumlah & Persentase \\
\hline 1 & Lambatnya respon complain & 58 & 16,48 \\
\hline 2 & Pengiriman barang tidak tepat waktu & 52 & 14,78 \\
\hline 3 & Tidak ada refund & 20 & 5,68 \\
\hline 4 & Dugaan penipuan & 29 & 8,24 \\
\hline 5 & Barang yang dibeli tidak sesuai dengan yang diterima & 114 & 32,37 \\
\hline 6 & Barang yang diterima dalam kondisi cacat & 29 & 8,24 \\
\hline 7 & Kurangnya ketersediaan barang yang dijual & 34 & 9,66 \\
\hline 8 & Ganguan sistem dan jaringan & 10 & 2,84 \\
\hline 9 & Lainnya & 6 & 1,70 \\
\hline & Jumlah & 352 & 100 \\
\hline
\end{tabular}

Sumber: Data Penelitian diolah, 2019

Berdasarkan hasil penelitian diatas maka dapat terlihat dengan jelas dari 8 (delapan) jenis keluhan yang ada maka keluhan terhadap barang yang dibeli tidak sesuai dengan yang diterima merupakan keluhan yang paling banyak dikeluhkan olehmasyarakat sebagai pengguna toko online yaitu sebesar $32,37 \%$. Kemudian terlihat juga keluhan lambatnya respon komplain, pengiriman barang tidak tepat waktu merupakan keluhan yang juga sering dirasakan oleh masyarakat. Keluhan lain yang juga dialami oleh masyarakat selain dari 8 (delapan) keluhan yang sudah dirumuskan yaitu harga dan biaya ongkos kirim yang mahal.

Untuk dapat mengetahui pengaruh kualitas layanan terhadap kepuasan masyarakat, maka peneliti harus merancang sebuah kuesioner yang berisi pernyataan untuk mengetahui berbagai persepsi konsumen. Variabel kualitas layanan sebagai variabel bebas terbagi dalam 5 (lima) dimensi yaitu: tangible (X1), reliability (X2), responsiveness (X3), assurance (X4), empathy (X5). Setiap variabel bebas memiliki 2 (dua) indikator dituangkan menjadi 4 (empat) butir pernyataan sehingga total pernyataan untuk variabel kualitas pelayanan adalah 20 (dua puluh) pernyataan. Variabel kepuasan masyarakat sebagai variabel terikat (Y) terbagi ke dalam 5 (lima) indikator. Setiap indikator dituangkan menjadi 2 (dua) pernyataan sehingga total pernyataan untuk variabel kepuasan masyarakat adalah 10 (sepuluh) pernyataan.

Pernyataan-pernyataan tersebut digunakan dengan metode skala Likert sehingga jawaban memiliki 5 (lima) pernyataan yaitu:

Nilai 1 : Tidak setuju / tidak memuaskan

Nilai 2 : Kurang setuju / kurang memuaskan

Nilai 3 : Setuju /memuaskan

Nilai 4 : Setuju sekali / memuaskan sekali

Nilai 5 :Sangat setuju sekali /sangat memuaskan sekali 


\section{Pengujian Validitas dan Reliabilitas}

Nilai korelasi yang diperoleh setiap butir instrumen pernyataan harus positif dan kemudian dibandingkan dengan nilai $r_{\text {tabel }}$ dengan kriteria apabila $r_{\text {hitung } \geq} r_{\text {tabel }}$ maka butir instrumen pernyataan tersebut adalah valid. Apabila nilai $\mathrm{r}_{\text {hitung }}\left\langle\mathrm{r}_{\text {tabel }}\right.$ maka butir instrumen pernyataan tersebut tidak valid sehingga tidak layak untuk dijadikan butir didalam instrumen pernyataan penelitian. Berdasarkan $\mathrm{r}_{\text {tabel }}$ maka untuk responden berjumlah 30 (tiga puluh) orang dan nilai taraf signifikan 5\% maka diperoleh nilai $\mathrm{r}_{\text {tabel }}=0,361$. Hasil pengujian setiap butir instrumen pernyataan untuk setiap variabel penelitian dapat dilihat pada tabel dibawah ini.

Tabel 5. Hasil Uji Validitas Instrumen Pernyataan Variabel Tangible $\left(\mathrm{X}_{1}\right)$

\begin{tabular}{|l|l|c|l|}
\hline No & \multicolumn{1}{|c|}{ Pernyataan } & Nilai Korelasi & Ket \\
\hline 1 & $\begin{array}{l}\text { Produk yang dibeli dapat bertahan dalam jangka waktu } \\
\text { yang lama }\end{array}$ & 0,722 & Valid \\
\hline 2 & Ketersediaan produk yang diperlukan konsumen & 0,733 & Valid \\
\hline 3 & $\begin{array}{l}\text { Kemudahan akses toko online melalui laptop, } \\
\text { komputer maupun smartphone }\end{array}$ & 0,831 & Valid \\
\hline 4 & Produk yang dipesan sesuai dengan yang diterima & 0,657 & Valid \\
\hline
\end{tabular}

Sumber: Data Penelitian, diolah 2019

Berdasarkan tabel 5 menunjukkan bahwa pengujian instrumen pernyataan variabel tangible $\left(\mathrm{X}_{1}\right)$ memiliki nilai $\mathrm{r}_{\text {hitung }}>\mathrm{r}_{\text {tabel }}(0,361)$, dengan demikian seluruh butir instrumen pernyataan penelitian adalah valid sehingga sudah tepat untuk mengukur variabel tangible $\left(\mathrm{X}_{1}\right)$.

Tabel 6.Hasil Uji Validitas Instrumen Pernyataan Variabel Reliability $\left(\mathrm{X}_{2}\right)$

\begin{tabular}{|l|l|l|l|}
\hline No & \multicolumn{1}{|c|}{ Pernyataan } & Nilai Korelasi & Ket \\
\hline 1 & $\begin{array}{l}\text { Kemudahan dalam melakukan pendaftaran/regristrasi } \\
\text { pada website toko online }\end{array}$ & 0,615 & Valid \\
\hline 2 & Jenis dan keunggulan produk dimuat dengan jelas & 0,645 & Valid \\
\hline 3 & $\begin{array}{l}\text { Tata letak/lay out website memudahkan dalam proses } \\
\text { pembelian produk }\end{array}$ & 0,716 & Valid \\
\hline 4 & Harga setiap produk terjangkau oleh konsumen & 0,639 & Valid \\
\hline
\end{tabular}

Sumber: Data Penelitian, diolah 2019

Berdasarkan tabel 6 menunjukkan bahwa pengujian instrumen pernyataan variabel reability $\left(\mathrm{X}_{2}\right)$ memiliki nilai $\mathrm{r}_{\text {hitung }}>\mathrm{r}_{\text {tabel }}(0,361)$, dengan demikian seluruh butir instrumen pernyataan penelitian adalah valid sehingga sudah tepat untuk mengukur variabel reability $\left(\mathrm{X}_{2}\right)$. 
Tabel 7. Hasil Uji Validitas Instrumen Pernyataan Variabel Responsiveness $\left(\mathrm{X}_{3}\right)$

\begin{tabular}{|l|l|l|l|}
\hline No & \multicolumn{1}{|c|}{ Pernyataan } & Nilai Korelasi & Ket \\
\hline 1 & $\begin{array}{l}\text { Segala jenis promosi dapat dinikmati langsung oleh } \\
\text { konsumen }\end{array}$ & 0,487 & Valid \\
\hline 2 & Produk yang dibeli sampai tujuan dengan aman & 0,644 & Valid \\
\hline 3 & $\begin{array}{l}\text { Pihak Toko Online melakukan pengawasan terhadap } \\
\text { produk yang dipesan dari awal pemesanan sampai } \\
\text { produk diterima oleh konsumen }\end{array}$ & 0,848 & Valid \\
\hline 4 & Produk yang dijual legal secara hukum & 0,720 & Valid \\
\hline
\end{tabular}

Sumber: Data Penelitian, diolah 2019

Berdasarkan tabel 7 menunjukkan bahwa pengujian instrumen pernyataan variabel responsiveness $\left(\mathrm{X}_{3}\right)$ memiliki nilai $\mathrm{r}_{\text {hitung }} \geq \mathrm{r}_{\text {tabel }}(0,361)$, dengan demikian seluruh butir instrumen pernyataan penelitian adalah valid sehingga sudah tepat untuk mengukur variabel responsiveness $\left(\mathrm{X}_{3}\right)$.

Tabel 8. Hasil Uji Validitas Instrumen Pernyataan Variabel Assurance $\left(\mathrm{X}_{4}\right)$

\begin{tabular}{|l|l|l|l|}
\hline No & \multicolumn{1}{|c|}{ Pernyataan } & Nilai Korelasi & Ket \\
\hline 1 & $\begin{array}{l}\text { Kerusakan produk yang diterima konsumen dapat } \\
\text { diganti dengan produk yang baru }\end{array}$ & 0,873 & Valid \\
\hline 2 & Data pelanggan terjamin kerahasiaannya & 0,747 & Valid \\
\hline 3 & Layanan pemesanan dapat dilakukan selama 24 jam & 0,746 & Valid \\
\hline 4 & $\begin{array}{l}\text { Produk yang dipesan sampai tepat pada waktu yang } \\
\text { ditentukan }\end{array}$ & 0,816 & Valid \\
\hline
\end{tabular}

Sumber: Data Penelitian, diolah 2019

Berdasarkan tabel 8 menunjukkan bahwa pengujian instrumen pernyataan variabel assurance $\left(\mathrm{X}_{4}\right)$ memiliki nilai $\mathrm{r}_{\text {hitung }}>\mathrm{r}_{\text {tabel }}(0,361)$, dengan demikian seluruh butir instrumen pernyataan penelitian adalah valid sehingga sudah tepat untuk mengukur variabel assurance $\left(\mathrm{X}_{4}\right)$.

Tabel 9. Hasil Uji Validitas Instrumen Pernyataan Variabel Empathy $\left(\mathrm{X}_{5}\right)$

\begin{tabular}{|l|l|l|l|}
\hline No & \multicolumn{1}{|c|}{ Pernyataan } & Nilai Korelasi & Ket \\
\hline 1 & $\begin{array}{l}\text { Costumer service memiliki sikap peduli dan ramah } \\
\text { dalam menanggapi kesulitan yang dihadapi konsumen }\end{array}$ & 0,688 & Valid \\
\hline 2 & $\begin{array}{l}\text { Costumer service menanggapi setiap keluhan dengan } \\
\text { baik }\end{array}$ & 0,899 & Valid \\
\hline 3 & Promosi yang diberikan bermanfaat bagi konsumen & 0,659 & Valid \\
\hline 4 & Adanya promosi yang menarik & 0,849 & Valid \\
\hline
\end{tabular}

Sumber: Data Penelitian, diolah 2019 
Berdasarkan tabel 9 menunjukkan bahwa pengujian instrumen pernyataan variabel assurance $\left(\mathrm{X}_{5}\right)$ memiliki nilai $\mathrm{r}_{\text {hitung }}>\mathrm{r}_{\text {tabel }}(0,361)$, dengan demikian seluruh butir instrumen pernyataan penelitian adalah valid sehingga sudah tepat untuk mengukur variabel assurance $\left(\mathrm{X}_{5}\right)$.

Tabel 10. Hasil Uji Validitas Instrumen Pernyataan Variabel Kepuasan Masyarakat (Y)

\begin{tabular}{|l|l|l|l|}
\hline No & \multicolumn{1}{|c|}{ Pernyataan } & Nilai Korelasi & Ket \\
\hline 1 & $\begin{array}{l}\text { Kemudahan memilih produk sesuai dengan kebutuhan } \\
\text { konsumen }\end{array}$ & 0,684 & Valid \\
\hline 2 & Kemudahan dalam pembayaran & 0,626 & Valid \\
\hline 3 & Produk yang dijual aman untuk digunakan & 0,684 & Valid \\
\hline 4 & Proses pembayaran yang aman & 0,704 & Valid \\
\hline 5 & Proses pemesanan produk dilakukan dengan cepat & 0,694 & Valid \\
\hline 6 & Keluhan konsumen ditanggapi dengan cepat & 0,689 & Valid \\
\hline 7 & $\begin{array}{l}\text { Setiap keluhan konsumen ditanggapi oleh costumer } \\
\text { service }\end{array}$ & 0,764 & Valid \\
\hline 8 & $\begin{array}{l}\text { Promosi dapat tersampaikan dengan baik kepada } \\
\text { konsumen }\end{array}$ & 0,667 & Valid \\
\hline 9 & Promosi yang diberikan menguntungkan konsumen & 0,655 & Valid \\
\hline 10 & $\begin{array}{l}\text { Pelanggan mempunyai media untuk menyampaikan } \\
\text { keluhan }\end{array}$ & 0,634 & Valid \\
\hline
\end{tabular}

Sumber: Data Penelitian, diolah 2019

Berdasarkan tabel 10 menunjukkan bahwa pengujian instrumen pernyataan variabel kepuasan masyarakat $(\mathrm{Y})$ memiliki nilai $\mathrm{r}_{\text {hitung } \geq \mathrm{r}_{\text {tabel }}}(0,361)$, dengan demikian seluruh butir instrumen pernyataan penelitian adalah valid sehingga sudah tepat untuk mengukur variabel kepuasan masyarakat (Y).

Setelah semua butir instrumen pernyataan setiap variabel dinyatakan valid maka pengujian reliabilitas dapat dilakukan. Pengujian reliabilitas dilakukan untuk mengetahui sejauh mana hasil suatu pengukuran dapat dipercaya. Ada berbagai cara untuk melakukan pengujian reliabilitas, peneliti dalam hal ini melakukan pengujian reliabilitas dengan menggunakan metode nilai cronbanch's alpha. Pengujian dilakukan dengan menggunakan bantuan alat statistik software SPSS dengan kriteria penilaian suatu instrumen variabel penelitian memiliki reliabilitas yang tinggi jika nilai koefisien yang diperoleh > 0,60 (Noor, 2011). 
Hasil pengujian dapat dilihat pada tabel 11 dibawah ini:

Tabel 11.Hasil Uji Reliabilitas Variabel Penelitian

\begin{tabular}{|l|c|c|c|c|}
\hline No & Nama Variabel & $\begin{array}{c}\text { Nilai Cronbanch's } \\
\text { alpha }\end{array}$ & $\begin{array}{c}\text { Jumlah } \\
\text { pernyataan }\end{array}$ & Keterangan \\
\hline 1 & Tangible $\left(\mathrm{X}_{1}\right)$ & 0,736 & 4 & Reliabel \\
\hline 2 & Reliability $\left(\mathrm{X}_{2}\right)$ & 0,634 & 4 & Reliabel \\
\hline 3 & Responsiveness $\left(\mathrm{X}_{3}\right)$ & 0,624 & 4 & Reliabel \\
\hline 4 & Assurance $\left(\mathrm{X}_{4}\right)$ & 0,804 & 4 & Reliabel \\
\hline 5 & Empathy $\left(\mathrm{X}_{5}\right)$ & 0,783 & 4 & Reliabel \\
\hline 6 & Kepuasan Masyarakat $(\mathrm{Y})$ & 0,868 & 10 & Reliabel \\
\hline
\end{tabular}

Sumber: data diolah, 2019

Berdasarkan tabel 11 menunjukkan bahwa hasil pengujian setiap variabel penelitian memiliki nilai cronbanch's alpha $>0,60$, dengan demikian seluruh variabel penelitian adalah reliabel sehingga sudah dapat dipercaya untuk mengukur setiap variabel penelitian.

Penelitian selanjutnya akan menyebarkan kuesioner kepada 352 responden penelitian untuk mendapatkan persepsi konsumen Toko Online tentang analisis kualitas layanan terhadap kepuasan masyarakat Kota Medan.

\section{Pengujian Asumsi Klasik}

Kuesioner yang telah diisi oleh konsumen Toko Online kemudian di input keseluruhan data untuk dilanjutkan pengujian asumsi klasik dan analisis regresi berganda. Pengujian asumsi klasik dilakukan dengan penggunaan software SPSS, sebagai berikut:
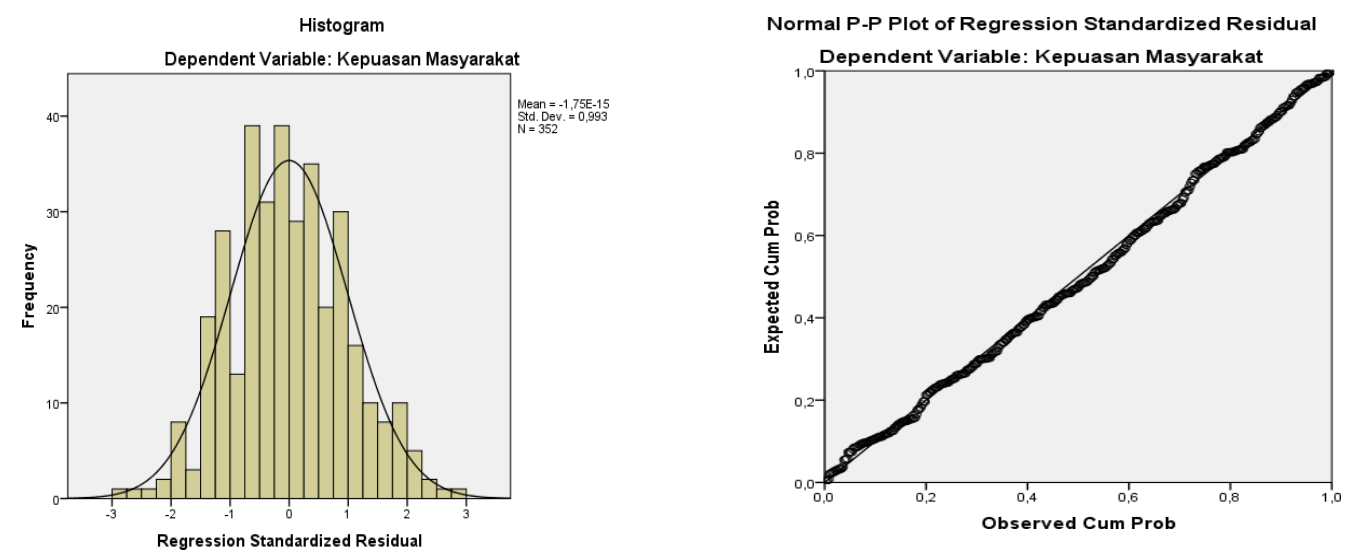

Gambar 1. Hasil Uji Normalitas

Sumber: data diolah, 2019 
Tabel 5. Hasil Uji Normalitas

One-Sample Kolmogorov-Smirnov Test

\begin{tabular}{|ll|r|}
\hline & & $\begin{array}{r}\text { Unstandardize } \\
\text { d Residual }\end{array}$ \\
\hline $\mathrm{N}$ & & 352 \\
Normal & Mean &, 0000000 \\
Parameters & Std. & 3,14153489 \\
a,b & Deviation \\
Most Extrem & Absolute & \\
& Positive &, 033 \\
e Differences & Negative &, 033 \\
& &,- 026 \\
Test Statistic & ) &, 033 \\
Asymp. Sig. (2- & & $, 200 \mathrm{c}, \mathrm{d}$ \\
tailed & & \\
\hline
\end{tabular}

a. Test distribution isNormal.

b. Calculated fromdata.

c. Lilliefors SignificanceCorrection.

d. This is a lower bound of the truesignificance.

Sumber: data diolah, 2019

Berdasarkan hasil pengujian asumsi klasik terlihat bahwa pada gambar histogram menunjukkan pola distribusi normal dan gambar normal P-Plot juga menunjukkan penyebaran pola distribusi garis diagonal dan mengikuti arah garis diagonalnya. Hasil ini juga diperkuat dengan uji statistik Kolmogorov Smirnov Test yang memperlihatkan hasil signifikansi lebih besar dari 0,05 maka dengan demikian model regresi analisis data penelitian berdistribusi normal.

Tabel 12. Hasil Uji Multikolinieritas

\begin{tabular}{|c|c|c|c|c|c|}
\hline \multirow{2}{*}{\multicolumn{2}{|c|}{ Model }} & \multicolumn{2}{|c|}{$\begin{array}{l}\text { Unstandardized } \\
\text { Coefficients }\end{array}$} & \multicolumn{2}{|c|}{$\begin{array}{l}\text { Collinearity } \\
\text { Statistics }\end{array}$} \\
\hline & & $B$ & Std. Error & $\begin{array}{l}\text { Toleranc } \\
\mathrm{e}\end{array}$ & $\begin{array}{l}\mathrm{VI} \\
\mathrm{F}\end{array}$ \\
\hline \multirow[t]{6}{*}{1} & (Constant) & 4,580 & 1,128 & & \\
\hline & Tangible & ,295 &, 109 & ,432 & 2,312 \\
\hline & Reliability &, 571 &, 101 & ,459 & 2,181 \\
\hline & Responsiveness & ,281 & ,108 & ,433 & 2,308 \\
\hline & Assurance &, 530 & , 107 & ,423 & 2,362 \\
\hline & Empathy & ,483 &, 101 & ,439 & 2,278 \\
\hline
\end{tabular}

Sumber: data diolah, 2019 
Pengujian multikolinieritas bertujuan untuk menguji apakah model regresi ditentukan adanya korelasi antara variabel bebas (independen). Berdasarkan hasil pengujian di atas dapat dilihat bahwa nilai tolerance setiap variabel bebas lebih besar dari 0,10 dan nilai VIF setiap variabel bebas lebih kecil dari 10 maka dapat disimpulkan bahwa model regresi analisis penelitian terbebas dari multikolinieritas.

Tabel 13. Hasil Uji Heteroskedastisitas

Coefficients ${ }^{a}$

\begin{tabular}{|c|c|c|c|c|c|c|}
\hline \multirow[b]{2}{*}{ Mod } & & \multicolumn{2}{|c|}{ Unstandardized Coefficients } & $\begin{array}{l}\text { Standardized } \\
\text { Coefficients }\end{array}$ & \multirow[b]{2}{*}{$\mathrm{t}$} & \multirow[b]{2}{*}{ Sig. } \\
\hline & & $B$ & Std. Error & Beta & & \\
\hline \multirow[t]{6}{*}{1} & (Constant) & 2,565 & ,672 & & 3,814 &, 000 \\
\hline & Tangible & ,061 & ,065 & ,076 & ,939 & 348 \\
\hline & Reliability &,- 090 & ,060 &,- 117 & $-1,488$ & 138 \\
\hline & Responsiveness & ,009 & ,064 & 012 & 146 & 884 \\
\hline & Assurance & ,086 & ,064 & 110 & 1,343 & 180 \\
\hline & Empathy &,- 070 & ,060 &,- 093 & $-1,155$ & 249 \\
\hline
\end{tabular}

a. Dependent Variable: RES2

Sumber: Data diolah, 2019

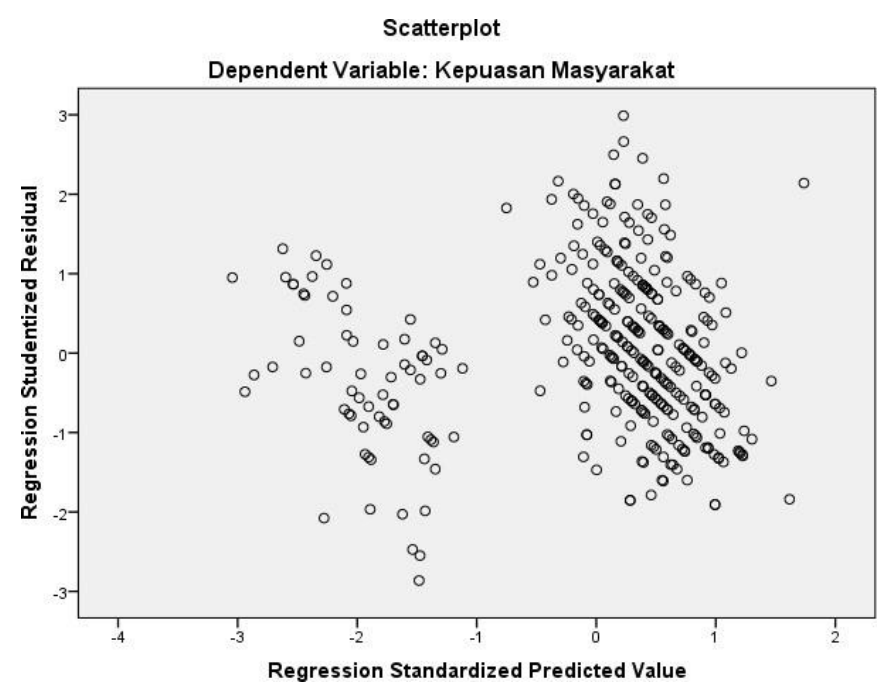

Gambar 2 Hasil Uji Heterokedastisitas

Sumber: Data diolah, 2019 
Berdasarkan hasil uji heteroskedastisitas pada gambar scatter plot terlihat data menyebar tetapi masih menumpuk disatu area sehingga untuk memastikan data telah terbebas dari heterokedastisitas maka dilakukan uji statistik dengan uji park maka diperoleh nilai signifikansi setiap variabel bebas adalah lebih besar dari 0,05 sehingga data model regresi analisis penelitian telah terbebas dari heterokedastisitas.

\section{HASIL DAN DISKUSI}

Hasil penelitian telah menunjukkan bahwa kualitas layanan Toko Online berpengaruh terhadap pencapaian tingkat kepuasan bertransaksi masyarakat di Kota Medan, dengan demikian seluruh variabel kualitas layanan yang ada yaitu tangible, reliability, responsiveness, assurance dan empathy merupakan bagian yang harus terus diperhatikan dan dikembangkan untuk semakin lebih baik sehingga dapat memberikan peningkatan kepuasan kepada konsumen Toko Online. Kualitas layanan yang diberikan harus terukur sehingga dapat diketahui pencapaian akhir dari sebuah proses layanan yang telah dilakukan. Untuk mengukur kualitas layanan. (Rahmayanty, 2013) Dalam mengevaluasijasayang bersifat intangible (tak berwujud fisik), pelanggan umumnya menggunakan beberapa atribut berikut:

1. Bukti langsung (tangibles), meliputi fasilitas fisik, perlengkapan, pegawai, dan saranakomunikasi

2. Keandalan (reliability), kemampuan memberikan pelayanan yang dijanjikan dengan segera, akurat danmemuaskan

3. Daya tanggap (responsiveness), keinginan para staff dan karyawan untuk membantu pelanggan dan memberikan pelayanan dengan cepattanggap

4. Jaminan (assurance), mencakup pengetahuan, kemampuan, kesopanan, dan sifat dapat dipercaya yang dimiliki para staff; bebas dari bahaya, risiko atau keraguraguan.

5. Empati (empathy), meliputi kemudahan dalam melakukan hubungan, komunikasi yang baik, perhatian pribadi dan memahami kebutuhan pelanggan.

Perusahaan Toko Online harus memperhatikan dengan serius tentang kualitas layanan yang diberikan sehingga dapat terus meningkatkan kepuasan konsumen, melakukan evaluasi dan tindakan responsif yang tepat untuk melakukan perbaikan sesuai yang dibutuhkan pelanggan saatini. Peneliti akan melanjutkan untuk menguji dari kelima faktor tersebut agar diketahui faktor mana merupakan faktor dominan yang mempengaruhi kepuasan konsumen Toko Online. Hasil pengujian yang dilakukan dengan uji t maka dapat diketahui faktor mana yang dominan yang mempengaruhi kualitas layanan adalah reliability (X1) dengan nilai thitung 5,642 . Variabel reliability yang tercermin dari 2 (dua) indikator yaitu pelayanan yang akurat dan 
pelayanan yang sesuai dengan dijanjikan. Kedua indikator tersebut kemudian dipecah menjadi 4 (empat) pernyataan dalam kuesioner penelitian yaitu, kemudahan dalam melakukan pendaftaran/regristrasi pada website toko online, tata letak/lay out website memudahkan dalam proses pembelian produk, jenis dan keunggulan produk dimuat dengan jelas serta harga setiap produk lebih terjangkau oleh konsumen.

Dengan demikian terlihat jelas bahwa persepsi masyarakat yang tertinggi tentang kualitas layanan Toko Online terletak pada variabel reliability sehingga perusahaan Toko Online harus dengan lebih baik mengelola dan meningkatkan kualitas layanan yang dimiliki sebagai upaya peningkatan kepuasan konsumen Toko Online di KotaMedan.

\section{KESIMPULAN}

Untuk mendapatkan hasil penelitian dengan informasi yang lebih akurat dan terpercaya maka peneliti juga berupaya untuk mendapatkan persepsi dari pengelola yaitu Perusahaan toko online. Dalam hal ini peneliti berencana akan melakukan wawancara untuk mengetahui bagaimana respon dari perusahaan toko online terhadap berbagai keluhan masyarakat kota Medan yang menggunakan jasa mereka. Setelah peneliti memberikan hasil penelitian ini dan saran kepada para perusahaan toko online maka diharapkan ada respon nyata dari pihak perusahaan toko online. Perusahaan toko online juga diharapkan memberikan gambaran dan penjelasan tentang upaya perbaikan yang dilakukan untuk dapat meningkatkan kepuasan bertransaksi masyarakat kota Medan.

Berdasarkan hasil penelitian di atas terlihat jelas bahwa konsumen toko online merasakan berbagai keluhan yang secara nyata mengganggu kepuasan bertransaksi dalam keseharian. Dalam hal ini maka sangat diharapkan adanya tindakan nyata dari perusahaan toko online untuk memberikan perbaikan sehingga para konsumen toko online mendapatkan kualitas layanan yang lebih baik. Perusahaan toko online seharusnya terus berbenah diri untuk meningkatkan penggunaan teknologi yang update untuk dapat memenuhi kebutuhan masyarakat yang semakin beragam terhadap jasa transaksi elektronik terutama penggunaan akses internet. Perusahaan toko online harus memiliki persiapan teknis yang baik untuk menghadapi jam padat/sibuk penggunaan transaksi elektornik sehingga gangguan sistem/jaringan tidak terjadi. Perusahaan toko online agar lebih transaparan terhadap produk yang dijajakan sehingga dapat meminimalisir ketidaksesuaian pesanan produk yang dibeli dengan yang diterima.

Kesadaran perusahaan toko online agar dengan cepat melayani segala keluhan masyarakat, hal ini merupakan yang paling penting sehingga masyarakat sebagai pengguna merasa diperhatikan dan didengarkan. Semua upaya perusahaan toko online untuk melakukan perbaikan kualitas layanan sangat diharapkan masyarakat sehingga kedepannya akan terjadi perbaikan yang nyata yang dapat dirasakan oleh masyarakat. 


\section{REFERENSI}

Arianto, N. (2018). Pengaruh kualitas pelayanan terhadap kepuasan dan loyalitas pengunjung dalam menggunakan jasa Hotel Rizen Kedaton Bogor. Jurnal Pemasaran Kompetitif, 1.

Isra, jose, T. (2017). Pengaruh Kualitas Pelayanan terhadap Kepuasan Konsumen Uber Car. Jurnal Manajemen Universitas Telkom, 4.

Kriyantono, R. (2007). Teknis Praktis Riset Komunikasi (Pertama). Kencana.

Lupiyoadi, R. (2006). Manajemen Pemasaran Jasa (2nd ed.). Salemba Empat.

Mowen, J. C. (2002). Perilaku Konsumen (Kelima). Erlangga.

Muhammad, A. (2014). Manajemen Pemasaran Jasa. Alfabeta.

Nirmala, R. (2018). Konsumen Banyak Keluhkan Pelayanan Toko Daring. https://beritagar.id/artikel/berita/konsumen-banyak-keluhkan-pelayanan-toko-daring

Pratama, A. H. (2016). (Update) Kumpulan Toko Online Popular di Indonesia. https://id.techinasia.com/toko-online-populer-di-indonesia

Rahmayanty, N. (2013). Manajemen Pelayanan Prima (Pertama). Graha Ilmu.

Rakhmat, J. (2004). Metode Penelitian Komunikasi. PT. Remaja Rosdakarya.

Wijayanto, K. (2015). Pengaruh kualitas pelayanan terhadap kepuasan nasabah Bank. Jurnal Ekonomi Manajemen Sumber Daya Universitas Muhammadiyah Surakarta, 17.

Yamit, Z. (2013). Manajemen Kualitas Produk dan Jasa (Keenam). Ekonesia.

Zuhra, W. U. N. (2017). Menanti RPP Perdagangan Elektronik Yang Tak Kunjung di Sahkan. https://tirto.id/menanti-rpp-perdagangan-elektronik-yang-tak-kunjung-disahkan-cucU https://onlineterpercaya.com/2017/02/16/berita-terkini-tentang-perkembangan-bisnis-onlineindonesia/

https://katadata.co.id/berita/2018/01/19/ylki-keluhan-terbanyak-konsumen-selama-2017-soal-tokoonline 